\title{
Terminator 2, Judgment Day
}

\author{
RAlPh FoOTRING, Scientific Editor, British Journal of Psychiatry
}

How would you feel about a sequel to One Flew $O$ ver the Cuckoo's Nest, set in the present? I am writing about the next best thing: Terminator 2, subtitled Judgment Day, sequel to the 1984 film Terminator, both starring Arnold Schwarzenegger in the eponymous role. Terminator 2 , reputedly the most expensive film ever made, was released last August. Guild, its distributor, expect the film (certificate 15) in the UK to gross $£ 17$ million and to be seen by 6 million people, with a similar audience when it is released on video.

The film, set in the US, in the present, is about a humanoid robot - the terminator-sent back from the future to kill John Connor, a boy who is due to lead the human resistance in the war against the machines that follows World War III (Judgment Day), which is itself begun by the defence computer. The first film was similar, except that a terminator was sent back to 1984 to kill the boy's mother, Sarah Connor, so that John would never be born. It fails, but Sarah learns of her son's destiny.

Between the two films, Sarah is left to raise a saviour of the race and knowing the date of World War III. When she tries to blow up a computer factory in order to prevent the war, she is apprehended. Terminator 2 begins at the time when she is in "Pescadero State Hospital", a special hospital for women. Sarah is first shown doing pull-ups in her cell, on an up-ended bed. Her cell is small, with one barred window, a toilet, and a basin. The door has a small window with speaker beneath. The cell is white. The whole hospital is white, clean, high-tech, and secure. I wish my home were, but this is a bit unnerving in the public sector.

Dr Silberman, Sarah Connor's psychiatrist, played by Earl Boen, enters the film leading a team of junior doctors, wearing, yes, white coats, through the corridors, past patients wearing white uniforms and being led, disturbed and cowering, by uniformed orderlies carrying truncheons. Silberman is explaining the interesting case of Sarah Connor: "The delusional architecture is unique", he says, and he elaborates on the robots sent to kill her. "That's original!" says a junior. Silberman chuckles. Perhaps he is sardonic enough to suggest that psychiatry is not all fun at the expense of patients.

They reach the cell and peer in, at the patient exercising on her up-ended bed. This is evidently more an 18th-century-style recreational tour than a

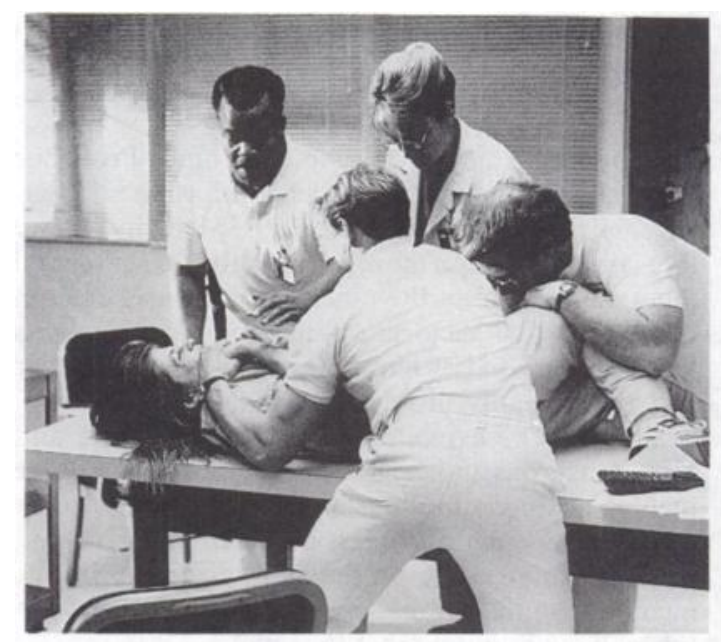

Hollywood shows restraint. (Copyright Carolco International)

case conference. Sarah asks Silberman, "How's the knee?" He is abashed and has to explain to the juniors that the patient has managed to stab him with a pen a few weeks previously. "See that she takes her Thorazine", he says, complaining that she has disrupted her room. This illuminates the role of drugs in the therapeutic milieu. Fortunately, perhaps, little else is seen of treatment.

The diagnosis is interesting. Silberman explains that Connor is suffering from "acute schizoaffective disorder". For the less expert in the audience, her son has previously described her as "a complete psycho". The patient holds a very specific set of 'delusions', which are in fact true. All she does is rational and consistent with these beliefs. She does not improve on medication. She is not, and she is not meant to be, believably insane.

When the film returns to the hospital, Sarah and Dr Silberman are watching a video of a previous interview in which she is recounting her recurring nightmare about the nuclear holocaust. We are at least spared an analytical interpretation - Silberman comforts her (she is very distressed) that lots of people have dreams about the end of the world. Behind one-way mirrors, they are filmed watching the film. Silberman stops the video and Sarah says she is better now. She has a goal, something to look 
forward to. Silberman has told her that after six months, she might move to the minimum-security wing, where she can have a visit from her son, whom she is desperate to see. Six months have elapsed, and Sarah now says she does not believe the delusions. Silberman recognises that she is faking insight, he rightly believes she will try to escape if she is moved, and tells her that he will recommend to the review board that she stays another six months. She begs to see her son, at least to speak to him on the telephone. She is denied. She attacks Silberman, but is restrained (see picture), and injected with a drug that knocks her out. Silberman looks to the video camera and exclaims, "Model citizen!" At least there is a review board....

The last episode in the hospital begins with the police interviewing Sarah; Silberman lurks in the background. She is told that her son is missing; she pretends to become totally withdrawn, and steals a paperclip with which to effect an escape. A male orderly takes her back to her cell, and straps her to the bed, even though she has never shown any tendency to self-harm. He licks her slowly across the face, while she is still withdrawn. He locks her in the room, and walks off down the corridor, nonchalantly banging his truncheon against the cell doors.
Sarah picks the locks and runs off. Silberman is in the dispensary, with a nurse, and we hear him recommending an increase in dose (what else?) for a patient to $250 \mathrm{mg}$. Sarah nearly makes it out by holding a hypodermic full of "Liquid Rooter. Industrial Strength. Poison", from the dispensary, to Silberman's neck. In fact the terminator arrives for more general mayhem. Silberman sees it all, and in the last shot of him he looks washed up and rather foolish.

Terminator 2 is a good film. I and millions more enjoyed it. I saw psychiatry portrayed badly. Millions will have seen it simply portrayed. It is sad that this is done in terms of the old fears - the sane being locked away, drugged up, by the men in white coats. The drugs don't work, the staff don't care. Community care is side-stepped by making the heroine criminally insane, or worse, sane and while criminal, morally justified.

One final point is perhaps worth mentioning. World War III starts when the defence computer becomes 'self-aware', and when the terminator is asked whether it can be more human it says it can, the longer it spends with humans, because it has a "neural network". Given the prescience of some science fiction, can we chalk one up for biological psychiatry?

\section{Miscellany}

\section{Back issues of the Journal}

Complete volumes of The British Journal of Psychiatry from 1963-1982 are available free of charge from Mr Hugh Robertson, Home Office Research and Planning Unit, 50 Queen Anne's Gate, London SW1H 9AT (telephone 071273 2084).

\section{Information leafiets}

The following leaflets are available from the Mental Health Foundation, 8 Hallam Street, London W1N 6DH (telephone 071 5800145): Dementia and the Family, Mental Handicap and the Family, Problems of Alcohol, and Problems with Tranquillisers.

\section{Monograph on delirium}

The International Psychogeriatric Association (IPA) announces that a large special issue of International Psychogeriatrics, to be published in December 1991, will be devoted entirely to the subject of delirium. Membership in IPA is open to all interested in the field of psychogeriatrics ( $\$ 75.00$ for individuals, $\$ 150.00$ for institutions) and anyone who joins IPA before 31 December 1991 will receive the monograph as part of their membership. Those interested in membership, and non-members who wish to purchase the monograph separately, should contact: The Secretariat, IPA, 3127 Greenleaf A venue, Wilmette, IL 60091, USA (telephone 01017088667227 ; fax 01017088666984 ). 